\title{
TINGKAT KECEMASAN PADA PASIEN ANAK USIA SEKOLAH (6-12 TAHUN) DI RUANG IGD RSUD MAJALAYA KABUPATEN BANDUNG
}

\section{ANXIETY LEVEL IN SCHOOL-AGE PATIENTS (6-12 YEARS) IN THE EMERGENCY ROOM AT MAJALAYA REGIONAL HOSPITAL BANDUNG REGENCY}

\author{
Andria Pragholapati ${ }^{1}$, Yuyun Sarinengsih ${ }^{2}$, Susilawati ${ }^{3}$. \\ ${ }^{1}$ Departemen Keperawatan Jiwa, STIKes Jenderal Achmad Yani. \\ ${ }^{2}$ Departemen Keperawatan Anak, STIKes Bhakti Kencana. \\ ${ }^{3}$ RSUD Majalaya
}

\begin{abstract}
Anxiety arises because the child can not do what he wants and can only lie in bed. One of children's anxiety that occurs due to injuries to the body such as infusion and wound care. The effects of child anxiety on nurses include prolonged treatment and infusion often released because the child continues to rebel. The purpose of this study was to describe the level of anxiety in school-age children (6-12 years) in the emergency room at Majalaya Regional Hospital Bandung Regency 2017. The design of the study was a descriptive study, with a purposive sampling sample collection technique. Data collection was done by means of observation to respondents. Data was presented in the form of frequency distribution, with a sample of 93 people. Based on the results of the study note that anxiety in school-age child patients (6-12 years) in the emergency room Majalaya Regional Hospital Bandung regency mostly experienced anxiety as many as 72 people (77.4\%) and a small proportion did not experience anxiety as many as 21 people $(22.6 \%)$. Conclusions are found that the majority of school-age pediatric patients experience anxiety. Suggestions for nurses to be able to deal with all problems faced by patients and patients' families such as nurses are able to conduct therapeutic communication to calm patients.
\end{abstract}

Keywords: Anxiety, School Age Children, Emergency

\begin{abstract}
ABSTRAK
Kecemasan muncul karena anak tidak bisa melakukan apa yang diinginkan dan hanya bisa berbaring di tempat tidur. Kecemasan anak yang terjadi salah satunya akibat perlukaan pada tubuh seperti dilakukan infus dan perawatan luka. Efek dari kecemasan anak terhadap perawat diantaranya adalah tindakan perawatan lebih lama dan infus sering terlepas karena anak terus berontak. Tujuan penelitian ini adalah untuk mengetahui gambaran tingkat kecemasan pada pasien anak usia sekolah (6-12 tahun) di ruang IGD RSUD Majalaya
\end{abstract}


Kabupaten Bandung tahun 2017. Desain penelitian yang digunakan adalah jenis penelitian deskriptif, dengan teknik pengumpulan sampel purposive sampling. Pengumpulan data dilakukan dengan cara observasi kepada responden. Data disajikan dalam bentuk distribusi frekuensi, dengan sampel sebanyak 93 orang. Berdasarkan hasil penelitian diketahui bahwa kecemasan pada pasien anak usia sekolah (6-12 tahun) di ruang IGD RSUD Majalaya Kabupaten Bandung sebagian besar mengalami kecemasan sebanyak 72 orang $(77,4 \%)$ dan sebagian kecil tidak mengalami kecemasan sebanyak 21 orang $(22,6 \%)$. Simpulan didapatkan bahwa sebagian besar pasien anak usia sekolah mengalami kecemasan. Saran bagi perawat untuk mampu menghadapi segala permasalahan yang dihadapi oleh pasien dan keluarga pasien seperti perawat mampu melakukan komunikasi terapeutik untuk menenangkan pasien.

Kata Kunci : Kecemasan, Anak Usia Sekolah, IGD

\author{
Alamat Korespondensi : STIKes Jenderal Achmad Yani \\ Email : andria.pragholapati@gmail.com
}

\title{
PENDAHULUAN
}

Kondisi lingkungan IGD yang sibuk atau overcrowded menambah ketidaknyamanan dan menambah tingkat kecemasan pasien. Banyaknya pasien yang datang di IGD membuat perawat harus memilah pasien dengan cepat dan tepat sesuai prioritas bukan berdasarkan nomor antrian, di IGD banyak yang harus segera dilakukan perawatan terutama tindakan invasif (Igede, 2012). Tindakan invasif yang dilakukan di rumah sakit pada anak selama hospitalisasi sering menimbulkan trauma berkepanjangan. Tindakan invasif dapat berupa pemberian obat melalui penyuntikan, pemasangan infus, pengambilan spesimen darah dan jaringan, serta pembedahan. Tindakan invasif sering mengakibatkan nyeri dan dan menimbulkan bekas. Saat anak mengalami hospitalisasi tindakan invasif diberikan oleh perawat dalam asuhan mandiri atau kolaborasi dengan dokter (Howel, 2007). Anak akan bereaksi terhadap tindakan penusukan bahkan mungkin bereaksi untuk menarik diri terhadap jarum karena menimbulkan rasa nyeri yang nyata yang menyebabkan respon cemas (Wilson, 2007).

Kecemasan merupakan respon individu terhadap suatu keadaan yang tidak menyenangkan dan dialami oleh semua makhluk hidup dalam kehidupan seharihari (Suliswati, 2010). Respon anak terhadap lingkungan baru dapat beraneka ragam, perasaan cemas dapat timbul karena menghadapi sesuatu yang baru dan lingkungan yang tampak menakutkan dengan banyaknya orang yang tampak kesakitan. Respon anak terhadap perlukaan bisa menimbulkan kecemasan yang akan memperlihatkan ketidakmauan anak tersebut untuk dilakukan perlukaan, sehingga akhirnya anak akan berontak, menangis, menjerit dan tidak sedikit anak untuk minta pulang walaupun dalam kondisi yang sakit. (Salmela, 2009).

Penelitian diarahkan kepada anak usia sekolah (6-12 tahun) dikarenakan berdasarkan perkembangan psikososialnya anak pada usia ini dalam tahapan rajin dan akan selalu berusaha mencapai sesuatu yang diinginkan terutama apabila hal tersebut bernilai sosial atau bermanfaat bagi kelompoknya (Hurlock, 2010). Namun 
akibat adanya hospitalisasi maka kecemasan muncul karena anak tidak bisa melakukan apa yang diinginkan dan hanya bisa berbaring di tempat tidur. Kecemasan anak yang terjadi salah satunya akibat perlukaan pada tubuh seperti dilakukan infus dan perawatan luka.

Studi pendahuluan yang dilakukan di ruang IGD RSUD Majalaya Kabupaten Bandung jumlah pasien anak di ruang IGD periode bulan Januari sampai Juni 2016 sebanyak 2199 pasien dan untuk pasien dewasa sebanyak 4983 pasien, Untuk pasien anak dengan rincian usia di bawah 6 tahun (preschool) sebanyak 886 orang dan di atas 6 tahun (anak sekolah) sebanyak 1313 orang dengan rata-rata anak sekolah per bulan yaitu sebanyak 219 orang. Dari data tersebut dapat terlihat bahwa pasien lebih banyak pada usia sekolah. Hasil observasi yang dilakukan pada saat anak beberapa jam di ruang IGD terhadap 15 orang didapatkan bahwa 6 orang anak tampak meringis dan berontak sambil berteriak saat dilakukan tindakan pemasangan infus dan dua orang menangis pada saat datang ke ruang IGD dan mengajak kedua orangtuanya pulang, satu orang mengatakan bahwa takut pada dokter dan satu orang anak tampak marah-marah dengan wajah yang cemberut sehingga ditanyapun tidak menjawab, tiga orang anak menangis berontak ketika dibersihkan luka. Efek dari kecemasan anak terhadap perawat diantaranya adalah tindakan perawatan lebih lama dan infus sering terlepas karena anak terus berontak. Selanjutnya berdasarkan informasi dari perawat dan kepala ruangan di ruang IGD bahwa sampai saat ini belum pernah ada yang melakukan penelitian mengenai tingkat kecemasan pada pasien anak sekolah di ruang IGD RSUD Majalaya. Urgensi IGD yaitu untuk penanganan yang cepat dan tepat maka diperlukan adanya kooperatif anak pada saat dilakukan tindakan keperawatan.

Penelitian yang dilakukan oleh Elan Furwanti (2014) didapatkan hasil bahwa tingkat kecemasan pasien di IGD RSUD Panembahan Senopati Bantul banyak yang mengalami kcemasan berat $41,2 \%$ dan yang tidak mengalami kecemasan hanya 5,9\%. Tujuan dalam penelitian ini yaitu untuk mengetahui gambaran tingkat kecemasan pada pasien anak usia sekolah (6-12 tahun) di ruang IGD RSUD Majalaya Kabupaten Bandung tahun 2017

\section{METODE PENELITIAN}

Jenis penelitian yang digunakan dalam penelitian ini adalah penelitian deskriptif. Dalam penelitian ini ingin mengetahui mengenai tingkat kecemasan pada pasien anak usia sekolah (6-12 tahun) di ruang IGD RSUD Majalaya Kabupaten Bandung tahun 2017. Populasi dalam penelitian ini adalah pasien anak usia sekolah (6-12 tahun) yang dirawat di ruang IGD sesuai dengan jumlah studi pendahuluan yaitu sebanyak jumlah anak usia sekolah 219 orang. Sampel yang digunakan adalah pasien anak yang di rawat di IGD dengan pemilihan sampel menggunakan metode purposive sampling. Kategori dalam populasi ini berupa kriteria inklusi yang dibuat peneliti yaitu pasien triase kuning dan hijau dan pasien masa obsevasi 1-6 jam. Adapun kriteria eksklusinya adalah: anak usia kurang dari 6 tahun dan lebih dari 12 tahun dan pasien anak triase merah. Sampel yang digunakan pada penelitian ini sebanyak 93 pasien anak di ruang IGD. Penelitian ini dilakukan di ruang IGD RSUD Majalaya Kabupaten Bandung dengan waktu penelitian pada bulan Maret sampai Agustus 2017. 


\section{HASIL DAN DISKUSI}

Berdasarkan hasil penelitian, diketahui bahwa kecemasan pada pasien anak usia sekolah (6-12 tahun) di ruang IGD RSUD Majalaya Kabupaten Bandung sebagian besar mengalami kecemasan sebanyak 72 orang $(77,4 \%)$ dan sebagian kecil tidak mengalami kecemasan sebanyak 21 orang $(22,6 \%)$; dan kecemasan pada pasien anak usia sekolah (6-12 tahun) di ruang IGD RSUD Majalaya Kabupaten Bandung dilihat dari sub variabel gangguan fisik lebih dari setengahnya mengalami kecemasan sebanyak 53 orang (57\%), over sensitifitas lebih dari setengahnya mengalami kecemasan sebanyak 59 orang $(63,4 \%)$, gangguan konsentrasi lebih dari setengahnya mengalami kecemasan sebanyak 64 orang $(68,8 \%)$ dan faktor pelengkap lebih dari setengahnya mengalami kecemasan sebanyak 56 orang $(60,2 \%)$. Untuk lebih jelasnya dapat dilihat dalam tabel berikut:

Tabel 4.1

Gambaran Kecemasan pada Pasien Anak Usia Sekolah (6-12 Tahun) di Ruang IGD RSUD Majalaya Kabupaten Bandung Tahun 2017

\begin{tabular}{cccc}
\hline No. & Kecemasan & Jumlah & Persentase (\%) \\
\hline 1 & Mengalami Kecemasan & 72 & 77,4 \\
2 & Tidak Mengalami Kecemasan & 21 & 22,6 \\
\hline \multicolumn{2}{c}{ Total } & $\mathbf{9 3}$ & $\mathbf{1 0 0}$ \\
\hline
\end{tabular}

Tabel 4.2

Gambaran Kecemasan pada Pasien Anak Usia Sekolah (6-12 Tahun) di Ruang IGD RSUD Majalaya Kabupaten Bandung Tahun 2017 Berdasarkan Subvariabel

\begin{tabular}{|c|c|c|c|}
\hline No. & Kecemasan & Jumlah & Persentase (\%) \\
\hline \multirow[t]{4}{*}{1} & Gangguan fisik & & \\
\hline & Mengalami Kecemasan & 53 & 57 \\
\hline & Tidak Mengalami Kecemasan & 40 & 43 \\
\hline & $\begin{array}{c}\text { Total } \\
\end{array}$ & 93 & 100 \\
\hline \multirow[t]{4}{*}{2} & Over Sensitifitas (Kekhawatiran) & & \\
\hline & Mengalami Kecemasan & 59 & 63,4 \\
\hline & Tidak Mengalami Kecemasan & 34 & 36,6 \\
\hline & $\begin{array}{c}\text { Total } \\
\end{array}$ & 93 & 100 \\
\hline \multirow[t]{4}{*}{3} & Gangguan Konsentrasi & & \\
\hline & Mengalami Kecemasan & 64 & 68,8 \\
\hline & Tidak Mengalami Kecemasan & 29 & 31,2 \\
\hline & Total & 93 & 100 \\
\hline
\end{tabular}

4 Faktor Pelengkap 


\begin{tabular}{ccc}
\hline Mengalami Kecemasan & 56 & 60,2 \\
Tidak Mengalami Kecemasan & 37 & 39,8 \\
\hline Total & $\mathbf{9 3}$ & $\mathbf{1 0 0}$ \\
\hline
\end{tabular}

Kecemasan merupakan kekhawatiran yang tidak jelas dan menyebar yang berkaitan dengan perasaan tidak pasti dan tidak berdaya. Keadaan emosi ini tidak memiliki objek yang spesifik dan dialami secara subjektif (Stuart, 2006). Kecemasan adalah suatu perasaan takut yang tidak menyenangkan dan tidak dapat dibenarkan yang sering disertai dengan gejala fisiologis (Tomb, 2009). Kecemasan dapat diekspresikan secara langsung melalui perubahan fisiologis dan perilaku (Kaplan dkk., 2010). Maka dapat dikatakan bahwa hasil dari kecemasan dapat terlihat secara langsung berdasarkan perubahan fisiologis dan perilaku.

Berbagai macam aktivitas perawatan yang ada di ruang IGD akan menimbulkan kecemasan karena merasa kehilangan lingkungan yang dirasakanya aman, penuh kasih sayang, dan menyenangkan. Anak harus meninggalkan lingkungan rumah yang dikenalnya, permainan, dan teman sepermainannya (Supartini, 2010). Perubahan lingkungan fisik ruangan seperti fasilitas tempat tidur, suara yang gaduh akibat adanya orang lain yang kesakitan dapat membuat anak merasa terganggu dan menimbulkan kecemasan. Beberapa perubahan lingkungan fisik ini selama dirawat di rumah sakit dapat membuat anak merasa asing.

Selain lingkungan faktor yang bisa menyebabkan kecemasan terhadap anak yaitu adanya tindakan invasif. Tindakan invasif salah satunya berupa pemasangan infus. Pemasangan infus adalah suatu implementasi keperawatan yang dilakukan perawat untuk memasukan cairan atau obat langsung ke dalam pembuluh darah vena dalam jumlah banyak dan dalam waktu lama dengan menggunakan set infus secara bertetes. Pemasangan infus merupakan prosedur yang paling banyak dilakukan di rumah sakit. Pemasangan infus yang didapat anak pada saat masuk rumah sakit menimbulkan trauma berkepanjangan. Salah satu prosedur pemasangan infus yang dilakukan pada anak adalah terapi melalui pemasangan infus. Pemasangan infus merupakan prosedur yang menimbulkan rasa tidak nyaman, ketakutan dan kecemasan (Mubin, 2010).

Adanya faktor lingkungan dan tindakan invasif, kecemasan anak tidak terlepas dari peran keluarga terutama orang tua begitu penting dalam perawatan anak di rumah sakit karena pada dasarnya setiap asuhan pada anak yang dirawat di rumah sakit memerlukan keterlibatan orang tua (Supartini, 2010). Faktor-faktor seperti lingkungan, tindakan invasif dan peran orang tua menjadi faktor penyebab terjadinya kecemasan yang bisa terjadi pada anak usia sekolah, dengan adanya rasa sakit yang diderita anak usia sekolah telah mampu mengkomunikasikan rasa sakit yang mereka alami dan menunjukkan lokasi nyeri tersebut. Respon kecemasan bisa muncul dengan adanya ringan atau beratnya sakit yang diderita (Mubin, 2010).

Berdasarkan beberapa pendapat di atas, dikaitkan dengan hasil penelitian didapatkan sebagian besar anak mengalami kecemasan sebanyak 72 orang $(77,4 \%)$. Hal ini terjadi karena banyak faktor pencetus diantaranya lingkungan rumah sakit yang asing bagi adanya tindakan invasif, peran orangtua dalam pendampingan dan juga sakit yang diderita oleh anak. Selain itu juga banyaknya kondisi anak yang mengalami kecemasan dikarenakan usia anak paling banyak pada usia 6-9 tahun dengan kondisi anak yang masih sering menangis dan berontak ketika dilakukan 
tindakan keperawatan. Serta dilihat dari jenis kelamin banyak dengan jenis kelamin perempuan. Begitupun dengan pengalaman di rawat banyak yang baru pertama kali di rawat di IGD sebanyak 80 orang $(86 \%)$.

Dilihat dari nilai yang paling banyak mengalami kecemasan yaitu pada pertanyaan nomor 19 mengenai anak ketakutan dengan kondisi sekarang dan takut hal yang buruk terjadi sehingga lama di rawat di rumah sakit. Kondisi tersebut muncul karena anak merasakan adanya sakit pada tubuhnya sehingga merasa takut dan hal buruk terjadi pada dirinya dan juga anak pasti ingin cepat meninggalkan rumah sakit sehingga anak takut untuk lama di rawat di rumah sakit. Hasil penelitian menunjukkan banyak responden yang mengalami kecemasan. Oleh karena itu diperlukan adanya tindakan komunikasi terapeutik yang dilakukan oleh perawat untuk mengatasi kecemasan yang diderita oleh anak usia sekolah.

\section{SIMPULAN DAN SARAN}

Simpulan dalam penelitian ini yaitu: gambaran kecemasan pada pasien anak usia sekolah (6-12 tahun) di ruang IGD RSUD Majalaya Kabupaten Bandung tahun 2017 dengan sampel sebanyak 93 orang maka dapat diambil simpulan bahwa sebagian besar mengalami kecemasan sebanyak 72 orang $(77,4 \%)$ dan sebagian kecil tidak mengalami kecemasan sebanyak 21 orang $(22,6 \%)$. Berdasarkan hasil penelitian perawat senantiasa mampu menghadapi segala permasalahan yang dihadapi oleh pasien dan keluarga pasien seperti perawat mampu melakukan komunikasi terapeutik untuk menenangkan pasien pada saat pasien merasakan sakit dan ketakutan berada di rumah sakit.

\section{DAFTAR PUSTAKA}

1. Alfiyanti. (2007). Asuhan Keperawatan pada Kehamilan Fisiologi dan Patologis. Jakarta: Salemba Medika.

2. Cecil R. Reynolds, dan Bert O. Richmond. (2008). Revised Children's Manfiest Anxiety Scale. Second Edition. Retrived from http://www.wpspublish.com /store/p/2934/revised-childrens-manifest-anxiety-scale-second-edition-rcmas2

3. Gunarso. (2010). Pengantar Psikologi. Jakarta: Mutiara.

4. Hambly. (2010). Rahasia Membangun Kepercayaan Diri. Jakarta: Puspa Swara

5. Howel. (2007). Keperawatan Anak Sakit. Jakarta: EGC.

6. Hurlock. (2010). Psikologi Perkembangan Suatu Pendekatan Sepanjang Rentang Kehidupan, Edisi 5. Jakarta: Erlangga

7. Igede. (2012). Psikologi untuk Keperawatan. Jakarta: EGC.

8. Keliat, B.A. (2011). Model Praktik Keperawatan Profesional Jiwa. Jakarta: EGC.

9. Mubin, M. Fatkhul. (2010). Faktor-faktor yang berhubungan dengan Kecemasan pada Anak Usia Prasekolah di Bangsal Melati RSUD Tugurejo Semarang. Universitas Muhammadiyah Semarang.

10. Musliha. (2010). Keperawatan Gawat Darurat. Yogyakarta : Nuha Medika

11. Rochman. (2010). Kesehatan Mental. Purwokerto: Fajar Media Press. 
12. Salmela. (2009). Buku Ajar Keperawatan Pskiatirik. Jakarta: EGC.

13. Sarinti. (2007). Asuhan Keperawatan. Yogyakarta: Nuha Medika.

14. Soetjiningsih. (2010). Tumbuh Kembang Anak. Jakarta: EGC.

15. Stuart. (2006). Buku Saku Keperawatan Jiwa. Edisi 3. Alih Bahasa Akhir Yani S. Jakarta : EGC.

16. Suliswati. (2010). Konsep Dasar Keperawatan Jiwa. Edisi I. Jakarta: EGC.

17. Supartini. (2010). Buku Ajar konsep Dasar Keperawatan Anak. Jakarta. EGC

18. Vacarolis, E. M. (2008). Pschiatric Nursing Clinical Guide: Assesment Tools \& Diagnosis. Philadelphia: W.B. Saunders Company.

19. Wijayanti. (2009). Panduan Belajar: Keperawatan Ibu-Bayi Baru Lahir. Jakarta: EGC.

20. Wilson. (2007). Patofisiologi Konsep Klinis Proses-Proses Penyakit. Alih Bahasa: dr. Brahm U. Jakarta: EGC.

21. Wong, L. Donna. (2008). Buku Ajar Keperawatan Pediatrik. Vol. 1. Edisi 6. Jakarta: EGC. 